\title{
Correlation between Age and Body Mass Index (BMI) with Histopathological Features of Breast Cancer Patients in RSUP Haji Adam Malik Medan
}

\author{
Harisa Mardiah ${ }^{1 *}$, Radita Nur Anggaeni ${ }^{2}$, Heru Rahmadhany ${ }^{3}$, Esther Reny Deswany ${ }^{2}$ \\ ${ }^{1}$ Medical Faculty, University of Sumatera Utara, Medan, Indonesia \\ ${ }^{2}$ Histology Department, Medical Faculty, University of Sumatera Utara, Medan, Indonesia \\ ${ }^{3}$ Surgical Department, Medical Faculty, University of Sumatera Utara, Medan, Indonesia
}

\section{ARTICLE INFO}

Received : 14 January 2020

Reviewed : 16 April 2020

Accepted : 04 January 2021

Keywords:

age, breast cancer, BMI,

histopathological features

*Corresponding author:

Harisa Mardiah

Medical Faculty, University of

Sumatera Utara, Medan, Indonesia

harisamardiah48@gmail.com

\begin{abstract}
A BSTRACT
Background: Breast cancer is influenced by various risk factors, including age and obesity. Older women who are overweighted and obese have a higher risk of developing breast cancer. This study aims to find the correlation between age and body mass index (BMI) with histopathological features of breast cancer patients in RSUP Haji Adam Malik Medan.
\end{abstract}

Methods: This research is an analytical study using a cross-sectional design with 103 samples obtained from medical record data by random sampling. The data obtained were then adjusted to the research criteria and grouped based on predetermined variables.

Results: The majority of the age group was $41-50$ years (36.9\%), obesity BMI (40.8\%), histopathological subtype of invasive carcinoma of no special type (NST) (85.4\%), and grade II (46.6\%). Kruskal-Wallis test result between histopathological subtypes and breast cancer grading based on age, respectively, obtained $p=0.503, r=.325 ;(\alpha>0.05)$, and $p=0.207, r=0.393 ;(\alpha>0.05)$, while based on BMI obtained $p=0.017, r=0.021 ;(\alpha<0.05)$, and $p=0.018, r=0.018 ;(\alpha<0.05)$. The OR value $(95 \% \mathrm{Cl})$ obtained on overweight-obese BMI with invasive carcinoma NST subtype was 7.63 (7.27-14.90) and other subtypes were 2.40 (1.14-13.75), and for grades II and III, they were respectively $3.57(1.32-8.09)$ and $3.27(1.17-9.91)$.

Conclusions: There was a correlation between BMI with histopathological subtypes and breast cancer grading, but the correlation tended to be weak. Whereas, with age, there was no correlation. BMI overweight-obese were more likely to have invasive carcinoma NST subtype and higher-grade of breast cancer.

\section{INTRODUCTION}

Breast cancer is a malignant tumor formed from abnormal breast cells that grow and develop uncontrollably so that it can spread between the tissues or organs around the breast or other body parts [1]. Globally, breast cancer is the most common cancer type, contributing to 2.1 million cases each year. In 2018, an estimated 627,000 women died of breast cancer, about $15 \%$ of all cancer deaths among women [2]. Breast cancer was the second largest cause of death in Indonesia, with about $19.18 \%$ or 58,256 cases in 2018 [3].

The risk of breast cancer increases with age and is mostly found in women aged 50 years or older. An older woman who has been menopaused with over- weight and obesity has a higher risk of developing breast cancer than normal weight [4]. Overweight and obesity are defined as abnormal or excessive fat accumulation that presents a risk to health [5]. Body mass index (BMI) is calculated using the formula of a person's body weight (in kilograms) divided by the square of his height (in meters) [6]. BMI is categorized as underweight (BMI $<18.5 \mathrm{~kg} / \mathrm{m}^{2}$ ), normal (BMI 18.5 to $22.9 \mathrm{~kg} / \mathrm{m}^{2}$ ), overweight (BMI 23 to $24.9 \mathrm{~kg} / \mathrm{m}^{2}$ ), and obese (BMI $\geq 25$ $\mathrm{kg} / \mathrm{m}^{2}$ ).

Histopathologically, breast cancer is divided into noninvasive and invasive carcinoma. Invasive breast cancer is cancer that penetrates the ducts and lobes' walls and invades the surrounding fat and connective tissue [7]. 
Some subtypes of breast cancer are invasive carcinoma of no special type (NST), invasive lobular carcinoma, tubular carcinoma, medullary carcinoma, mucinous carcinoma, and invasive papillary carcinoma [8]. About $70-80 \%$ of cases fall into the category of invasive ductal carcinoma, followed by invasive lobular carcinoma, about 5-15\%. Invasive lobular carcinoma frequently occurs in women aged $>50$ years, while invasive ductal carcinoma is more common at the young age of $\leq 40$ [9].

The histologic grade reflects how far the tumor architecture and cytology deviate from normal and how rapidly it proliferates. Scoring the breast cancer grade uses the WHO criteria, namely Nottingham combined histologic grade (modified Scarff-Bloom-Richardson) [10]. Grade I is with 3-5 score that well-differentiated cancer, grade II with a score of 6-7 has a feature between grades I and III (moderately/intermediately differentiated). Grade III is an 8-9 score for cancers with poorly differentiated or undifferentiated, which cancer cells grow quickly and may spread [11]. In general, younger women were more likely to have higher-stage and higher-grade disease [12]. The previous studies have found associations between high BMI and high histologic grade levels $[13,14]$. The previous study implies that excess body weight contributes to higher tumor stage and grade, including a greater incidence of metastases, specifically in the $80 \%$ of breast tumors considered luminal [15].

In most studies, risk estimates for the relationship between body mass index (BMI) and breast cancer have been adjusted for tumor characteristics (stage at diagnosis and/or tumor size, grade, and nodal status) [15]. Also, obesity is associated with greater size, stage, and grade $[13,16]$. Numerous studies have documented that young women were more likely to develop more aggressive breast cancer subtypes with unfavorable prognostic features and present with more advanced disease stages [12]. Therefore, the researchers are interested in finding the correlation between age and BMI with histopathological features of breast cancer patients in RSUP Haji Adam Malik Medan in 2018. This study can be beneficial as knowledge and information regarding age and $\mathrm{BMI}$ correlate with breast cancer histopathology features.

\section{METHODS}

This type of research is an analytical study using a cross-sectional design. The study aimed to find the correlation between age and BMI with histopathological features of breast cancer patients in RSUP Haji Adam Malik Medan in 2018.

This study's population was all breast cancer patients hospitalized and diagnosed by histopathology from secondary data in the form of medical record data in RSUP Haji Adam Malik Medan in 2018, which were 378 patients. Histopathological feature variables in this study were histopathological subtypes and grading. This study's histopathological subtypes comprised invasive carcinoma of no special type (NST), invasive lobular carcinoma, tubular carcinoma, medullary carcinoma, mucinous carcinoma, and invasive papillary carcinoma. Meanwhile, this study's grading was grouped into grade I, grade II, and grade III, calculated based on the Nottingham histologic grade.

The minimum number of samples in this study was calculated employing the hypothesis test formula [17] and obtained the minimum number of samples was 97 patients. The samples was taken by random sampling and taken by sorting first, then grouped, and finally taken randomly from each of these groups.

The samples were adjusted to the research criteria in the form of inclusion and exclusion criteria [17]. The inclusion criteria were female patients diagnosed with breast cancer in RSUP Haji Adam Malik Medan in 2018, had clinical data such as age, height, and weight, and clear histopathological results on medical record data. The exclusion criteria were incomplete clinical data on breast cancer patients.

Then, the sample data obtained were grouped based on predetermined variables in which the criteria had been previously determined according to the operational definition. The first step in categorizing was to set the criteria in advance and how many categories to create. The age variable was categorized into four: age $\leq 40$ years, 41-50 years, 51-60 years, and age >60 years. $\mathrm{BMI}$ variable was classified into three: underweight (BMI $<18.5 \mathrm{~kg} / \mathrm{m}^{2}$ ), normal weight (BMI $18.5-22.9 \mathrm{~kg} / \mathrm{m}^{2}$ ), overweight-obese (BMI 23-24.9 and $>25 \mathrm{~kg} / \mathrm{m}^{2}$ ). Histopathological subtypes of breast cancer were grouped into six: invasive carcinoma NST, invasive lobular carcinoma, tubular carcinoma, medullary carcinoma, mucinous carcinoma, and invasive papillary carcinoma, then divided into invasive carcinoma NST and another invasive carcinoma (non-NST). Grades variables were categorized into three: grade I, grade II, and grade III.

The determination of this category was based on the assumption that the subject population scores were normally distributed. After getting the criteria for determining categorization, then matching the data in SPSS was needed. Because the data obtained were mostly in the form of numerical data, the data were converted into categories, including four age categories, three BMI categories, two histopathological subtype's categories, and three breast cancer grade categories, which were given a value code of $1-4$, where it started from the smallest to the largest value when inputting it in the SPSS application on a computer.

The data were processed and analyzed using the Kruskal-Wallis test to obtain a p-value that showed the correlation between the age variable and BMI with histopathological subtypes and grading of breast cancer. 
A $p$-value $<0.05$ means there is a correlation, while $>0.05$ means there is no correlation. Correlation analysis was conducted to determine the correlation coefficient's existence, which is the value that shows a strong/ whether or not relations between two variables exist. The common correlation coefficient was symbolized by the $r$-value that could vary from -1 to +1 using the Spearman test. The $r$-value, which is approaching -1 or +1 , shows a strong correlation, while the r-value of the coming 0 indicates the weak correlation. The positive coefficient value means the correlation is directly proportional, while the negative coefficient value means the correlation is inversely proportional. Besides, the OR value measured the association to illustrate the magnitude of the risk of an impact from exposure. A significant OR value can be seen from the $95 \%$ confidence interval value. The value of $O R<1$ is protective, $O R=1$ neutral (no difference), and $O R>1$ is risk [17].

This research had received permission from the Health Research Ethical Committee, Medical Faculty, University of Sumatera Utara/RSUP Haji Adam Malik Medan No: 123/TGL/KEPK FKUSU-RSUP HAM/2019 on August 8, 2019.

\section{RESULTS}

The number of breast cancer patients hospitalized in 2018 was 378, but there were 103 samples according to the study sample's criteria. Table 1 shows the frequency distribution based on age group, body mass index, familial history, menopause status, hormonal contraception, histopathological subtype, and breast cancer grading as follows.

The results showed that the largest age group of breast cancer was age $41-50$ years, as many as 38 patients, the age of $51-60$ years was 31 patients, $\leq 40$ years was 21 patients, and $>60$ years was 13 patients. The most BMI was obese BMI, with 42 patients, overweight BMI with 33 patients, normal BMI with 25 patients, and underweight BMI with 3 patients.

The result revealed that 73 patients did not have a familial history of breast cancer, while 30 patients had it. Status of menopause displayed post menopause was 52 patients, and pre-menopause was 51 patients. Most patients who did not use hormonal contraception were 58 patients, while 45 patients used it.

The majority of breast cancer histopathological subtypes were invasive carcinoma NST with 88 patients, invasive lobular carcinoma with 7 patients, mucinous carcinoma with 4 patients, invasive papillary carcinoma with 2 patients, tubular carcinoma, and medullary carcinoma with 1 patient. Most breast cancers were in grade II with 48 patients, grade I with 29 patients, and grade III with 26 patients. Figure 1 presents the histopathological features of breast cancer in each of the following subtypes.
Table 1. Frequency distribution

\begin{tabular}{|c|c|c|}
\hline Characteristics & $N=103$ & Percentage (\%) \\
\hline \multicolumn{3}{|l|}{ Age Group } \\
\hline$\leq 40$ years & 21 & 20.4 \\
\hline $41-50$ years & 38 & 36.9 \\
\hline $51-60$ years & 31 & 30.1 \\
\hline$>60$ years & 13 & 12.6 \\
\hline \multicolumn{3}{|l|}{ Body Mass Index } \\
\hline Underweight & 3 & 2.9 \\
\hline Normal & 25 & 24.3 \\
\hline Overweight & 33 & 32 \\
\hline Obese & 42 & 40.8 \\
\hline \multicolumn{3}{|l|}{ Familial History } \\
\hline Yes & 30 & 29.1 \\
\hline No & 73 & 70.9 \\
\hline \multicolumn{3}{|l|}{ Menopause Status } \\
\hline Post menopause & 52 & 50.5 \\
\hline Pre menopause & 51 & 49.5 \\
\hline \multicolumn{3}{|l|}{ Hormonal Contraception } \\
\hline Yes & 45 & 43.7 \\
\hline No & 58 & 56.3 \\
\hline \multicolumn{3}{|l|}{ Histopathological Subtypes } \\
\hline $\begin{array}{l}\text { Invasive carcinoma } \\
\text { of no special type }\end{array}$ & 88 & 85.4 \\
\hline $\begin{array}{l}\text { Invasive lobular } \\
\text { carcinoma }\end{array}$ & 7 & 6.8 \\
\hline Tubular carcinoma & 1 & 1.0 \\
\hline Medullary carcinoma & 1 & 1.0 \\
\hline Mucinous carcinoma & 4 & 3.9 \\
\hline $\begin{array}{l}\text { Invasive papillary } \\
\text { carcinoma }\end{array}$ & 2 & 1.9 \\
\hline \multicolumn{3}{|l|}{ Grading } \\
\hline Grade 1 & 29 & 28.2 \\
\hline Grade 2 & 48 & 46.6 \\
\hline Grade 3 & 26 & 25.2 \\
\hline
\end{tabular}

The proportion and correlation of age and body mass index (BMI) according to histopathological subtype

Table 2 presents the proportion and correlation of age group and BMI based on histopathological subtypes. The proportion of age with a histopathological subtype of breast cancer showed that most patients were age 41-50 years, 30 patients (29.1\%) had invasive carcinoma NST. Kruskal-Wallis test results obtained a $p=0.503$, meaning no significant correlation between age with a histopathological subtype of breast cancer. The obtained $r$-value $=0.325$ with correlation coefficient $=0.098$ signified that there was no strong linear correlation between 

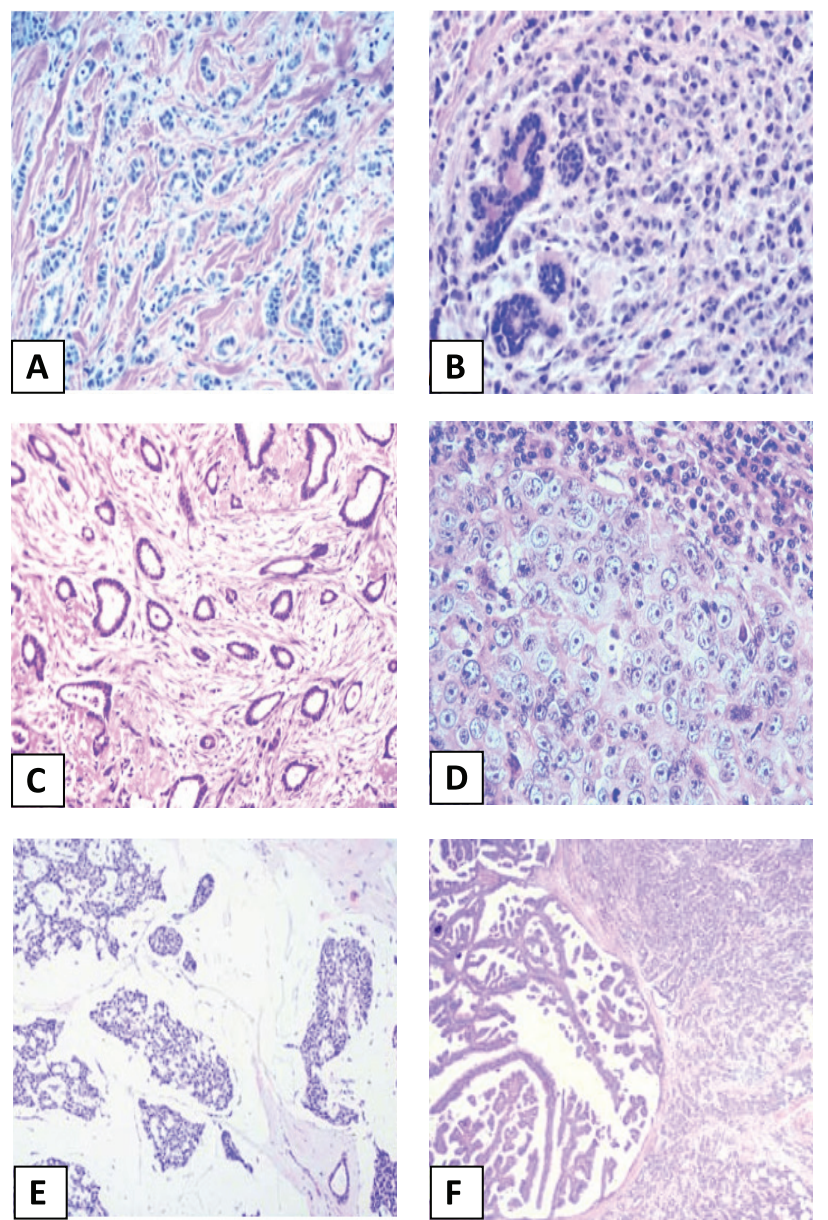

Figure 1. Overview of breast cancer histopathology. (A) Invasive carcinoma of no special type (NST); (B) Invasive lobular carcinoma; (C) Tubular carcinoma; (D) Medullary carcinoma; (E) Mucinous carcinoma; (F) Invasive papillary carcinoma. age with a histopathological subtype of breast cancer. The OR value $(95 \% \mathrm{Cl})$ obtained related to age with the histopathological subtype of breast cancer was considered insignificant because the value obtained was $<1$, so that the OR value in the population where the samples were taken was protective exposure to risk exposure.

Meanwhile, the proportion of BMI with histopathological subtypes revealed that patients with overweightobese IMT were 68 patients (66.0\%) with invasive carcinoma NST. Then, the Kruskal-Wallis test results obtained $p=0.017$. It is known that a significant value $\alpha<0.05$ denoted that BMI correlated with a histopathological subtype of breast cancer. Besides, the $r$-value $=0.021$ with correlation coefficient $=0.227^{*}$ showed a positive correlation but tended to be weak. The OR value $(95 \% \mathrm{Cl})$ obtained on overweight-obese $\mathrm{BMI}$ with histopathological subtypes, namely invasive carcinoma NST, was 7.63 (7.27-14.90), and other subtypes were 2.40 (1.135-13.75). For the normal weight BMI with invasive carcinoma NST, it was 3.11 (1.96-15.84), and other subtypes were 2.57 (1.45-14.37). It indicated that the risk of getting a histopathological subtype in the form of invasive carcinoma NST was 7.6 times greater in patients with overweight to obese.

\section{The proportion and correlation of age and BMI according to breast cancer grading}

Table 3 presents the proportion and correlation of age group and BMI based on breast cancer grading. The most breast cancer grading of each age group had grades II. The Kruskal-Wallis test between age and breast

Table 2. Proportion and correlation of age and BMI according to histopathological subtypes.

\begin{tabular}{|c|c|c|c|c|c|c|}
\hline \multirow[b]{2}{*}{ Characteristics } & \multicolumn{4}{|c|}{ Histopathological Subtypes } & \multirow[b]{2}{*}{$\mathbf{p}$} & \multirow[b]{2}{*}{$\begin{array}{l}r \text { value } \\
\text { (Coefficient) }\end{array}$} \\
\hline & $\begin{array}{l}\text { Invasive } \\
\text { carcinoma NST } \\
\mathrm{N}(\%)\end{array}$ & OR $(95 \% \mathrm{Cl})$ & $\begin{array}{l}\text { Other Subtypes } \\
\text { (Non-NST) } \\
\text { N (\%) }\end{array}$ & OR $(95 \% \mathrm{Cl})$ & & \\
\hline \multicolumn{7}{|l|}{ Age } \\
\hline$\leq 40$ years & $18(17.5 \%)$ & $0.50(0.05-5.39)$ & $3(2.9 \%)$ & $2.00(0.19-21.57)$ & \multirow{4}{*}{0.503} & \multirow{4}{*}{$\begin{array}{l}0.325 \\
(0.098)\end{array}$} \\
\hline $41-50$ years & $30(29.1 \%)$ & $0.31(0.04-2.78)$ & $8(7.8 \%)$ & $3.20(0.36-28.42)$ & & \\
\hline $51-60$ years & $28(27.2 \%)$ & $0.78(0.07-8.25)$ & $3(2.9 \%)$ & $1.29(0.12-13.65)$ & & \\
\hline$>60$ years & $12(11.7 \%)$ & $0.46(0.04-4.87)$ & $1(1.0 \%)$ & $0.96(0.08-10.94)$ & & \\
\hline \multicolumn{7}{|l|}{ Body Mass Index } \\
\hline Underweight & $3(2.9 \%)$ & $0.22(0.07-0.69)$ & $0(0 \%)$ & 0 & \multirow{3}{*}{0.017} & \multirow{3}{*}{$\begin{array}{l}0.021 \\
\left(0.227^{*}\right)\end{array}$} \\
\hline Normoweight & 17 (16.5\%) & $3.11(1.96-15.84)$ & $8(7.8 \%)$ & $2.57(1.45-14.37)$ & & \\
\hline Overweight-Obese & $68(66.0 \%)$ & 7.63 (7.27-14.90) & $7(6.8 \%)$ & $2.40(1.14-13.75)$ & & \\
\hline Total & $88(85.4 \%)$ & & 15 (14.6\%) & & & \\
\hline
\end{tabular}

* Correlation is significant at the 0.05 level 
Table 3. Proportion and correlation of age and BMI according to breast cancer grading.

\begin{tabular}{|c|c|c|c|c|c|c|c|c|}
\hline Characteristics & $\begin{array}{l}\text { Grade } 1 \\
\mathrm{~N}(\%)\end{array}$ & OR $(95 \% \mathrm{Cl})$ & $\begin{array}{c}\text { Grade } 2 \\
\text { N (\%) }\end{array}$ & OR $(95 \% \mathrm{Cl})$ & $\begin{array}{c}\text { Grade } 3 \\
\text { N (\%) }\end{array}$ & OR $(95 \% \mathrm{Cl})$ & $p$ & $\begin{array}{l}r \text { value } \\
\text { (Coefficient) }\end{array}$ \\
\hline Age & & & & & & & 0.207 & $\begin{array}{l}0.393 \\
(-0.085)\end{array}$ \\
\hline$\leq 40$ years & $\begin{array}{l}4 \\
(3.9 \%)\end{array}$ & $\begin{array}{l}0.20 \\
(0.03-1.53)\end{array}$ & $\begin{array}{l}9 \\
(8.7 \%)\end{array}$ & $\begin{array}{l}0.38 \\
(0.06-2.41)\end{array}$ & $\begin{array}{l}8 \\
(7.8 \%)\end{array}$ & $\begin{array}{l}0.32 \\
(0.04-2.34)\end{array}$ & & \\
\hline $41-50$ years & $\begin{array}{l}14 \\
(13.6 \%)\end{array}$ & $\begin{array}{l}0.70 \\
(0.11-4.48)\end{array}$ & $\begin{array}{l}16 \\
(15.5 \%)\end{array}$ & $\begin{array}{l}0.67 \\
(0.11-4.08)\end{array}$ & $\begin{array}{l}8 \\
(7.8 \%)\end{array}$ & $\begin{array}{l}0.32 \\
(0.04-2.34)\end{array}$ & & \\
\hline $51-60$ years & $\begin{array}{l}6 \\
(5.8 \%)\end{array}$ & $\begin{array}{l}0.30 \\
(0.04-2.11)\end{array}$ & $\begin{array}{l}17 \\
(16.5 \%)\end{array}$ & $\begin{array}{l}0.71 \\
(0.12-4.32)\end{array}$ & $\begin{array}{l}8 \\
(7.8 \%)\end{array}$ & $\begin{array}{l}0.32 \\
(0.04-2.34)\end{array}$ & & \\
\hline$>60$ years & $\begin{array}{l}5 \\
(4.9 \%)\end{array}$ & $\begin{array}{l}0.24 \\
(0.03-1.74)\end{array}$ & $\begin{array}{l}6 \\
(5.8 \%)\end{array}$ & $\begin{array}{l}0.23 \\
(0.03-1.68)\end{array}$ & $\begin{array}{l}2 \\
(1.9 \%)\end{array}$ & $\begin{array}{l}0.10 \\
(0.02-1.27)\end{array}$ & & \\
\hline Body Mass Index & & & & & & & 0.018 & 0.018 \\
\hline Underweight & $\begin{array}{l}3 \\
(2.9 \%)\end{array}$ & $\begin{array}{l}0.74 \\
(0.13-1.83)\end{array}$ & 0 & 0 & 0 & 0 & & \\
\hline Normoweight & $\begin{array}{l}10 \\
(9.7 \%)\end{array}$ & $\begin{array}{l}2.63 \\
(0.78-9.21)\end{array}$ & $\begin{array}{l}10 \\
(9.7 \%)\end{array}$ & $\begin{array}{l}1.11 \\
(0.33-3.66)\end{array}$ & $\begin{array}{l}5 \\
(4.9 \%)\end{array}$ & $\begin{array}{l}0.98 \\
(0.29-3.24)\end{array}$ & & \\
\hline Overweight-Obese & $\begin{array}{l}16 \\
(15.5 \%)\end{array}$ & $\begin{array}{l}2.95 \\
(0.97-9.86)\end{array}$ & $\begin{array}{l}38 \\
(36.9 \%)\end{array}$ & $\begin{array}{l}3.57 \\
(1.32-8.09)\end{array}$ & $\begin{array}{l}21 \\
(20.4 \%)\end{array}$ & $\begin{array}{l}3.27 \\
(1.17-9.91)\end{array}$ & & \\
\hline Total & $\begin{array}{l}29 \\
(28.2 \%)\end{array}$ & & $\begin{array}{l}48 \\
(46.6 \%)\end{array}$ & & $\begin{array}{l}26 \\
(25.2 \%)\end{array}$ & & & \\
\hline
\end{tabular}

* Correlation is significant at the 0.05 level

cancer grading obtained a $p=0.207$. The $r=0.393$ with correlation coefficient $=-0.085$ indicated no significant linear correlation. The OR value $(95 \% \mathrm{Cl})$ obtained at an age by grading breast cancer was considered insignificant because the value obtained was $<1$, so that the OR value in the population where the samples were taken was protective exposure to risk exposure.

The proportion of $\mathrm{BMI}$ with breast cancer grading uncovered that most patients with a BMI overweightobesity were 38 patients (36.9\%) with grade II breast cancer. The Kruskal-Wallis test results obtained $p=0.018$, revealing a significant value $\alpha<0.05$ so that there was a significant correlation between $\mathrm{BMI}$ with breast cancer grading. The obtained $r=0.018$ with correlation coefficient $=0.233^{*}$ showed that the correlation between BMI with breast cancer grading was positive but tended to be weak. The OR value $(95 \% \mathrm{Cl})$ obtained on overweight-obese BMI with breast cancer grading was in grades II and III, respectively, 3.57 (1.32-8.09) and 3.27 (1.17-9.91). It signified that the risk of getting breast cancer with grade II was 3.57 times more significant, and the risk of grade III was 3.27 times greater in patients with overweight to obese BMI than those who were not.

The most breast cancer grading of each age group had grades II. The Kruskal-Wallis test between age and breast cancer grading obtained a $p=0.207$. The $r=0.393$ with correlation coefficient $=-0.085$ indicated no significant linear correlation. The OR value $(95 \% \mathrm{Cl})$ obtained at an age by grading breast cancer was considered insignificant because the value obtained was $<1$, so that the $O R$ value in the population where the samples were taken was protective exposure to risk exposure.

The proportion of BMI with breast cancer grading uncovered that most patients with a BMI overweightobesity were 38 patients (36.9\%) with grade II breast cancer. The Kruskal-Wallis test results obtained $p=0.018$, revealing a significant value $\alpha<0.05$ so that there was a significant correlation between $\mathrm{BMI}$ with breast cancer grading. The obtained $r=0.018$ with correlation coefficient $=0.233^{*}$ showed that the correlation between BMI with breast cancer grading was positive but tended to be weak. The OR value $(95 \% \mathrm{Cl})$ obtained on overweight-obese $\mathrm{BMI}$ with breast cancer grading was in grades II and III, respectively, 3.57 (1.32-8.09) and 3.27 (1.17-9.91). It signified that the risk of getting breast cancer with grade II was 3.57 times more significant, and the risk of grade III was 3.27 times greater in patients with overweight to obese $\mathrm{BMI}$ than those who were not.

\section{DISCUSSION}

The incidence of breast cancer increases with age and in women who begin to transition to menopause [18]. Old or postmenopausal women, especially overweight and obese, have a higher risk of breast cancer. A woman's age is related to the occurrence of breast cancer. Because of increasing age, the cumulative amount of exposure received throughout that age is also getting 
higher; besides, physiologically, there is a decreased organ function and endurance [19].

Some studies have reported that a positive correlation between BMI and postmenopausal breast cancer risk only occurs among women with certain other risk factors, such as a family history of breast cancer or older age [18]. The potential differentiation of adipose stem cells is influenced by fat deposits, changes in the extracellular matrix, and increased BMI. On increasing $\mathrm{BMI}$ and obesity, adipose tissue expansion causes chronic inflammatory conditions that contribute to insulin resistance associated with obesity. This inflammatory state causes an increase in the pro-inflammatory circulation rate of cytokines, leptin, and insulin, where these factors are involved in developing breast cancer [20].

Based on the research results obtained, the most age group was $41-50$ years, as many as 38 patients (36.9\%). According to Rahmatya et al. [9] in Padang in 2012, most breast cancer patients were 40-49 years old, with an average age of 46.87 years. Therefore, increasing age would increase breast cancer risk, in which patients with age $\geq 40$ years had more risk than patients with age $<40$ years [21].

Further, the majority of breast cancer patients with obese BMI were 42 patients (40.8\%). Based on research carried out by Kawai et al. [22], a higher BMI (BMI = $25.8 \mathrm{~kg} / \mathrm{m}^{2}$ ) can increase the risk of breast cancer, and Berclaz et al. [23] disclosed that an increase in BMI was significantly associated with a worse prognosis in breast cancer [24].

A histopathological subtype was the most widely obtained invasive carcinoma of no special type (NST) as many as 88 patients (85.4\%). It aligns with research by Rahmatya et al. [9] that most had the invasive ductal carcinoma subtype, which was 40 cases (87.0\%). The majority of breast cancer grading was grade II with 48 patients (46.6\%). As reported in Firdaus et al. [25] research, more than half the sample was $62.1 \%$ with grade II, while research Firasi et al. [21] revealed 291 grade II patients (65.2\%).

Based on the test results obtained, $p=0.503, r=0.325$; $(\alpha>0.05)$, indicating no significant correlation between age and histopathological subtypes of breast cancer. It is supported by a study by Rahmatya et al. [9] that test results obtained with the chi-square statistic showed the $p=1.00$. Therefore, there was no difference in specific age groups for breast cancer in certain subtypes.

From the results between age and breast cancer grading, it was obtained $p=0.207$ and $r=0.393$; $(\alpha>0.05)$. It indicated no difference in certain age groups to specific breast cancer grading, and there was no strong linear correlation between age with a histopathological subtype of breast cancer. It is reinforced by Firasi et al. [21] research, which obtained a $p=0.189$. It denoted that the age-independent variable did not significantly correlate to the degree of differentiation of breast cancer.
In this study, it was probably caused by the number of samples in each variable group that did not vary.

Based on the results, it was obtained $p=0.017, r=0.021$; $(\alpha<0.05)$. It signified that BMI correlated with the histopathological subtype of breast cancer with a correlation coefficient $=0.243^{*}$. It showed that the correlation of both was positive but tended to be weak. The OR value $(95 \% \mathrm{Cl})$ obtained the risk of getting a histopathological subtype in the form of invasive carcinoma NST was 7.6 times greater in overweight and obese patients.

It is consistent with the study results by Gershuni et al. [26], revealing that the distribution of breast cancer subtypes varied significantly according to BMI status. Obesity might activate the other molecular pathway than the estrogenic circuit, which played a role in breast cancer pathogenesis. It is also verified by research by Suryani et al. [19] that a $p=0.012$ indicated a correlation between obesity factor and breast cancer incidence. Besides, another research obtained an OR value of 2.199, meaning that obese women had a risk of 2.199 bigger become breast cancer compared to women who were not obese [27].

This study's results showed that $p=0.018, r=0.018$; $(\alpha<0.05)$, indicating a significant correlation between $\mathrm{BMI}$ and breast cancer grading with correlation coefficient $=0.233^{*}$. It showed that the correlation was positive but tended to be weak. In accordance with research by Prawirohardjo et al. [11], a correlation coefficient of 0.396 with a $p=0.045$ signified that there was a significant correlation between body mass index and breast cancer grading [11]. Based on the OR value $(95 \% \mathrm{Cl})$ obtained, the risk of getting breast cancer with grade II was 3.57 times greater, and the risk of grade III was 3.27 times greater in patients with overweight or obese BMI than patients who were not.

Obesity is associated with chronic low-grade inflammation that has been reported to be an additional stimulus for tumor growth [14]. In increasing BMI and obesity, adipose tissue expansion causes chronic inflammation in conditions that contribute to insulin resistance, thereby causing an increase in the proinflammatory circulation of cytokines, leptin, and insulin as factors involved in the development of breast cancer [20]. Obese patients in the postmenopausal period have estrogenic production from adipose tissue, where IGF1 and insulin are growth factors [11]. The combined effects of both will decrease normal apoptosis and continuously stimulate cell division, which can cause breast cancer [19].

This study's limitations were related to obtaining research data and not discussing the difference between patients with breast cancer and patients without breast cancer. Moreover, other factors may be correlated with breast cancer. Further research is expected using better research design and discussing other factors that correlate with breast cancer occurrence. 


\section{CONCLUSIONS}

The study results showed a correlation of BMI with histopathological subtypes and breast cancer grading, but the correlation tended to be weak. Whereas, with age, there was no correlation. BMI overweight-obese were more likely to have Invasive carcinoma NST subtype and higher-grade of breast cancer. Although correlated, histopathological and grade subtypes appeared to be related to other breast cancer risk factors. Other factors that were not evaluated in our study could play a role. Increased BMI and obesity are associated with chronic inflammation, where growth factors are essential in the risk of developing breast cancer, especially molecular pathways. Therefore, further studies are needed to understand this relationship better.

\section{DECLARATIONS}

\section{Competing of Interest}

The authors declare no competing interest in this study.

\section{Ethics Approval}

This research has received permission from the Health Research Ethical Comittee, Medical Faculty, University of Sumatra Utara/RSUP Haji Adam Malik Medan No: 123/TGL/KEPK FKUSU-RSUP HAM/2019 on August 8, 2019.

\section{Funding Source}

This study was self-funded by the authors.

\section{Acknowledgement}

The authors wish to thank various parties at the Medical Faculty, University of Sumatera Utara that have given advice, criticism, suggestions, and support in the process of completing this research. We thank the editor and reviewers too for their comments and suggestions that helped us to improve the manuscript.

\section{REFERENCES}

1. Kementerian Kesehatan RI. InfoDatin, Pusat Data dan Informasi Kementerian Kesehatan RI Bulan Peduli Kanker Payudara 2016 [Internet]. 2016 [cited 2019 Apr 7]. Available from: http://www.depkes. go.id/article/view/17010500002/infodatin-kanker payudara.html

2. World Health Organization. Breast Cancer : Cancer [Internet]. 2019 [cited 2019 Apr 7]. Available from: https://www.who.int/cancer/prevention/diagnosisscreening/breast-cancer/en/

3. International Agency for Research on Cancer. Indonesia - Global Cancer Observatory [Internet]. 2019 [cited 2019 Apr 7]. Available from: http://gco. iarc.fr/today/data/factsheets/populations/360indonesia-fact-sheets.pdf

4. Centers for Disease Control and Prevention. What Are the Risk Factors for Breast Cancer? [Internet]. 2018 [cited 2019 Apr 14]. Available from: https:// www.cdc.gov/cancer/breast/basic_info/risk_factors. htm

5. World Health Organization. Obesity [Internet]. 2019 [cited 2019 Apr 14]. Available from: https://www. who.int/topics/obesity/en/

6. Centers of disease control. Body mass index: Considerations for practitioners. Cdc [Internet]. 2011;4. Available from: http://scholar.google.com/ scholar?hl=en\&btnG=Search\&q=intitle:Body+Mass+l ndex+:+Considerations+for+Practitioners\#3\%5Cnht tp://scholar.google.com/scholar?hl=en\&btnG=Searc $\mathrm{h} \& \mathrm{q}=$ intitle:Body+mass+index:+Considerations+for+ practitioners\%233

7. Lakhani SR, Ellis IO, Schnitt SJ, Tan PH, Van de VMJ (Eds). WHO Classifications of Tumours of the Breast. Lyon: IARC; 2012.

8. Lu Z, Chen J. Introduction of WHO classification of tumours of female reproductive organs, fourth edition. Chinese J Pathol. 2014;43(10):649-50.

9. Rahmatya A, Khambri D, Mulyani H. Hubungan usia dengan gambaran klinikopatologi kanker payudara di Bagian Bedah RSUP Dr. M. Djamil Padang. J Kesehat Andalas. 2015;4(2):478-84.

10. Hassan $O$. What is the Nottingham combined histologic grade (modified Scarff-Bloom-Richardson grade) system for breast tumors? Medscape [Internet]. 2019 [cited 2020 Mar 7]. Available from: https://www.medscape.com/answers/1668113$181367 /$ what-is-the-nottingham-combined-histologicgrade-modified-scarff-bloom-richardson-gradesystem-for-breast-tumors

11. Prawirohardjo AN, Soewoto W, Alfianto U. Hubungan index massa tubuh dengan grading pada kanker payudara. Biomedika. 2018;10(1):41-5.

12. Partridge $A H$, Hughes ME, Warner ET, et al. Subtypedependent relationship between young age at diagnosis and breast cancer survival. J Clin Oncol. 2016;34(27):3308-14.

13. Abubakar M, Chang-Claude J, Ali HR, et al. Etiology of hormone receptor positive breast cancer differs by levels of histologic grade and proliferation. Int J Cancer. 2018;143(4):746-57.

14. Laudisio D, Muscogiuri G, Barrea L, et al. Obesity and breast cancer in premenopausal women: Current evidence and future perspectives. Eur J Obstet Gynecol Reprod Biol. 2018;230:217-21.

15. Blair CK, Wiggins CL, Nibbe AM, et al. Obesity and survival among a cohort of breast cancer patients is partially mediated by tumor characteristics. npj Breast Cancer. 2019;5(1):1-7. 
16. Picon-Ruiz M, Morata-Tarifa C, Valle-Goffin JJ, et al. Obesity and adverse breast cancer risk and outcome: Mechanistic insights and strategies for intervention. CA Cancer J Clin. 2017;67(5):378-97.

17. Sastroasmoro, Sudigdo Ismael S. Dasar-Dasar Metodologi Penelitian Klinis. Fourth. Jakarta: Sagung Seto; 2017.

18. Dabbs D. Breast Pathology 2nd Edition [Internet]. Second. Canada: Elsevier Inc; 2017 [cited 2019 Apr 7]. Available from: https://www.elsevier.com/books/ breast-pathology/unknown/978-0-323-46236-5

19. Suryani R, Subandriyo HD, Yanti DE. Faktor resiko yang berhubungan dengan kejadian kanker payudara di Rumah Sakit Umum Daerah dr. H.Abdoel Moeloek Provinsi Lampung. J Kesehat. 2016;7(1):73.

20. Hillers LE, D'Amato J V, Chamberlin T, et al. Obesityactivated adipose-derived stromal cells promote breast cancer growth and invasion. Neoplasia. 2018;20(11):1161-74.

21. Firasi AA, Yudhanto E. Hubungan usia terhadap derajat diferensiasi kanker payudara pada wanita. JKD. 2016;5(4):327-36.
22. Kawai $M$, Minami $Y$, Nishino $Y$, et al. Body mass index and survival after breast cancer diagnosis in japanese women. BMC Cancer. 2012;12:149.

23. Berclaz G, Li S, Price K. Body mass index as a prognostic feature in operable breast cancer: The international breast cancer study group experience. Ann Oncol. 2004;15:875-84.

24. Sun LM, Zhu YM, Qian QM, Tang LM. Body mass index and prognosis of breast cancer - an analysis by menstruation status when breast cancer diagnosis. Medicine. 2018;97(26):1-2.

25. Firdaus V, Asri A, Khambri D. Hubungan grading histopatologi dan infiltrasi limfovaskular dengan subtipe molekuler pada kanker payudara invasif di Bagian Bedah RSUP. Dr. M. Djamil Padang. J Kesehat. 2016;5(1):165-72.

26. Gershuni V, Li YR, Williams AD, et al. Breast cancer subtype distribution is different in normal weight, overweight, and obese women. Breast Cancer Res Treat. 2017;163(2):375-81.

27. Irena R. Hubungan obesitas dengan kejadian kanker payudara di RSUD Bangkinang. PREPOTIF Jurnal Kesehatan Masyarakat. 2018;2(1):1-8. 